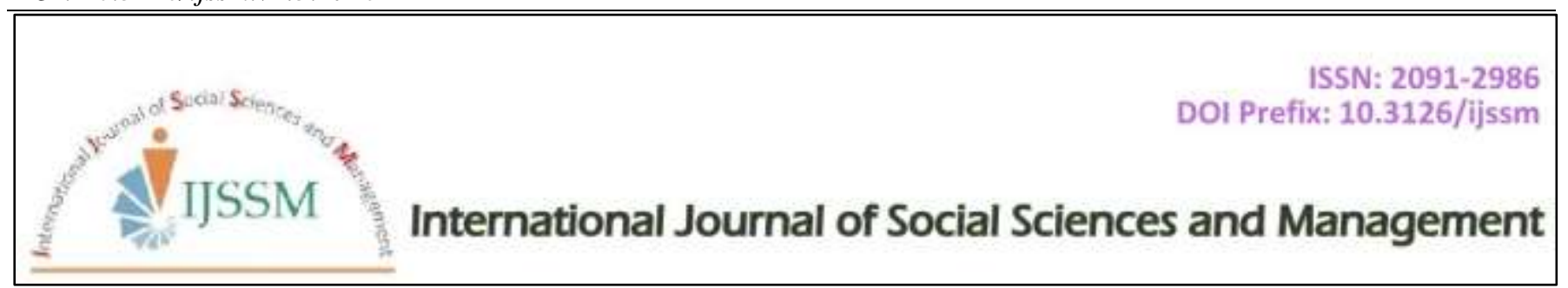

Case Study

\title{
Transnational Entrepreneurship and Ghanaians Abroad: What are the Motives? A Case Study in Europe and United States of America
}

\author{
Elvis Asiedu \\ Servicio Nacional de Aprendizaje (SENA), Business School, Department of Management Studies, Colombia
}

Email: elvisasiedu63@yahoo.com

\begin{abstract}
Using data collected from Ghanaians living in the United Kingdom, and the USA; this research examined the motives that drive the performance of transnational entrepreneurship, the mobility involves and why such businesses normally fail. The study was conducted in 2013-2017; with a population size of 120 Ghanaians living in the UK and the USA. The objective was to find out what really drives the performance of these entrepreneurs who operate in a condition where costs may be known but rewards are uncertain, yet they are motivated. The research employed both deductive and exploratory approach and the methods were both primary and secondary. The study focused on small-scale entrepreneurs who run their businesses through personal social connections.

The general results show that though individuals motives for seeking self-employment are diverse and numerous; and differ on certain points. However, there are some basic motives common to all and that is majority of the respondents with the average score of $63.3 \%$ supported that Economic Mobility, Financial Independence, Success Perspective, and Social Factors, are the most driven factors for the engagement in transnational entrepreneurship. We discovered that in a small-scale business, where most often do not have the needed managerial capabilities to engage in corporation, trust can be used to avoid loses that might come as a result of someone's misconduct. We also discovered that the successes of these entrepreneurs are based on attitudinal; the degree of embededdness in the home country; personal and the institutional regulations of the destination countries. The results found that Ghana Transnational Entrepreneurs (GTE) are more into Merchandising Business with (59.21\%) as compared to Service Business (34.21\%) and Manufacturing Business (10.53\%); and such businesses are managed and run mostly by their families $(59.21 \%)$. Ashanti Region of Ghana was spotted to be more involved in doing business with $52.63 \%$.
\end{abstract}

Key Words: Transnational Entrepreneurship; Ghana, Migration; Entrepreneurial Ventures; Social Relationship; Economic Mobility; Financial Independence.

Abbreviations: Transnational Entrepreneurship (T.E.); Ghana Transnational Entrepreneurs (G.T.E); Ghana Statistical Service (G.S.S).

\section{Introduction}

Ghana is considered one of the more stable countries in West Africa since its transition to multi-party democracy in 1992. Formerly known as the Gold Coast, the country gained independence from Great Britain on $6^{\text {th }}$ March, 1957 under the leadership of Dr. Kwame Nkrumah, thereby becoming the first country in sub-Saharan Africa to break the chains of colonialism. Ghana is ranked as the $86^{\text {th }}$ country with unemployment rate of $11 \%$ as of June, 30, 2015 as compared to $5.7 \%$ in the final quarter of 2013 (Ghana Statistical Service, 2013; IndexMundi 2016). Cocoa, Gold, Bauxite, Timber, and more recently Oil form the cornerstone of Ghana's economy and have helped fuel an economic growth. Ghana is the $9^{\text {th }}$ largest economy in Africa and $2^{\text {nd }}$ largest in West Africa, with 27 million populations (IndexMundi, 2016).

It is argued that, a country's economic development, employment, innovation and productivity are driven by entrepreneurial activities. Hisrich (2005) supported that economic progress of a country is significantly advanced by pragmatic individuals who are innovative with entrepreneurial skills, and willing to take risk in order to exploit opportunities that may be uncertain. Daniel and Mead (1998) argued that such enterprises play a major role 
in poverty alleviation for households and can be significant contributors to economic development of a country. In Ghana, the majority of the working populations are employed in small-scale enterprises. These small-medium enterprises employ $15 \%$ of the working population with a high rate of growth than any other companies and contributing $6 \%$ to the country's GDP (Kayanula and Quartey, (2000). That means the establishment of micro, small and medium enterprises contribute immensely to a country's economic growth. This has made the topic "transnational entrepreneurship", a popular area of research within the international business, ethnic and immigrant entrepreneurship.

Though transnational entrepreneurs are seen as the catalyst of these small-medium business establishments in Africa and within the context of Ghana, many of us have not sought to ask about their motives towards this establishment. Many of us are aware that establishing and managing business from a far distance can be very hectic and difficult; and as a matter of fact, these entrepreneurs operate in a condition where cost may be known but rewards are uncertain, yet they are motivated. Do you know that this kind of business creation requires someone who is hardworking, information seeking, independent-minded, and willing to take risk and personal initiative? Are you also aware that exploiting opportunities that may be uncertain could be the biggest risk to take as a transnational entrepreneur? So, if that is the case, then the question is; what really drives them to engage in such entrepreneurial activities?

Based on the present assumption, the study focused on the factors that drive the performance of small-medium entrepreneurs (SMEs) from Ghana, who run their businesses across international boundaries and borders, developing activities in socio-economic field at home and abroad through personal social connections; by answering the following research questions:

- What is transnational entrepreneurship? Is there any link between Migration and Entrepreneurial Ventures?

- What kind of influence do social relations, family and ethnic background have on transnational entrepreneurial success?

- What kind of businesses and industries are in the focus of Ghanaian transnational entrepreneurs?

- What are the motives for the performance of transnational entrepreneurship and why such businesses normally fail?

This study will go a long way to help the youth who wants to enter into entrepreneurship to know the risk, and the motives behind such establishment. It will also assist them to identify the factors that make such businesses fail sometimes. It focuses on Ghanaians abroad and their ties through personal social connections and the factors that drive the spirit of entrepreneurial activities as well as the kind of mobility involves in doing such businesses. However, not all the entrepreneurs the researcher met and interviewed were mobile, most of them used to travel to Ghana at least once a year to work for their businesses and maintain their relationship with their representatives.

\section{Literature Review}

\section{The Migration History of Ghanaians}

Many Ghanaians most especially; the youth constituting $33 \%$ of the country's population with $5.5 \%$ unemployment rate have sought to look for different means of employment; lo and behold, migration has been the alternative. Ghanaians have a history of migrating to Europe and America due to the country's cultural, socio-economic, colonial and political climate. Black and Castaldo (2008) advocated that Ghanaians are traditionally found of travelling to the United Kingdom and more recently to the United State of America. To buttress their point, they said "it was reflected in the sample with $40 \%$ of Ghanaian returnees interviewed coming from UK, and $21 \%$ from the United State of America". However, Ghana in recent years has experienced a diversification of migration destination just like other African countries (Black, 2004). They have created a social diaspora across the world and they keep increasing in their numbers and their contributions to the individual household and the country's economy cannot be over emphasized.

In 2010, a total number of 250,624 Ghanaians whose age ranges from 15 years and above were found living abroad. Out of the total population of 250, 624 Ghanaian abroad, $2 / 3^{\text {rd }}$ representing $6 \%$ were male and $1 / 3^{\text {rd }}$ representing $36 \%$ were females (Ghana Statistical Service, 2013). According to GSS (2013), 78.5\% of them between the ages of 20 years and 40 years were males and $77.5 \%$ were female. Statistical analysis show that, migrants from Ghana hail from all the ten regions in the country but the majority of them representing 52.8\% are from Ashanti and Greater Accra Region respectively. Table 1 shows the regions in Ghana with their migration percentage rate.

Table 1: Regions with high migration rate in Ghana

\begin{tabular}{|lll|}
\hline S.N. & Region & Migrants \% \\
\hline 1. & Ashanti & $27.6 \%$ \\
\hline 2. & Greater Accra & $25.2 \%$ \\
\hline 2. & Brong Ahafo & $13.4 \% \%$ \\
\hline 3. & Western & $8.7 \%$ \\
\hline 4. & Others & $25.1 \%$ \\
\hline
\end{tabular}

Source: Ghana Statistical Service (2013), Population and Housing Census, 2010. 
Among many countries in the world, Europe and America remain the most preferable destination for Ghanaian migrants with a total percentage of $61.3 \%$ respectively. According to Ghana Statistical Service, (2013), 37.7\% of Ghanaian migrants are believed to be in Europe, $23.6 \%$ are in America, 30.1\% in Cote d'Ivoire and 26.8\% in Togo. Anarfi et al.(2000) argued that the cultural and historical affinity can explain the reasons and importance behind these migration streams. Records also reveal that these migrants who are male are higher than females (Ghana Statistical Service, 2013) and this is the breakdown; $33.2 \%$ male migrants and $24.4 \%$ female migrants reside in ECOWAS countries such as Nigeria, Cote d'Ivoire, and Togo.

Similarly, $13.2 \%$ male and $5.5 \%$ female migrants were spotted living in other parts of Africa. In the words of Anarfi et al.(2000), Cote d'Ivoire has been a major destination for most Ghanaian female migrants and their activities in that country has attracted the attention of both academia and media. It has also been disclosed that each region in Ghana has its preferred destination and Fig. 1 shows the regions and their preferred country of destination.

When it comes to employment demarcation, over $76.2 \%$ of Ghanaians living abroad are employed, $6 \%$ are unemployed and $14 \%$ are students. The proportion employed according to Ghana Statistical Service (2013), grows from $42.8 \%$ (at age 15-19 years) to a peak of $85.4 \%$ (at age 50-54 years) before it declines again at the older age. Most of these people abroad are working as officials of Government and Special Interest Organisations, Professionals, Technicians and Associate Professionals, clerks, sales/service workers, farmers, fishermen and forestry workers, trade related workers, plant and machine operators, labourers and unskilled workers and special occupations. All these working groups contribute immensely to the total remittances sent to the country, Ghana.

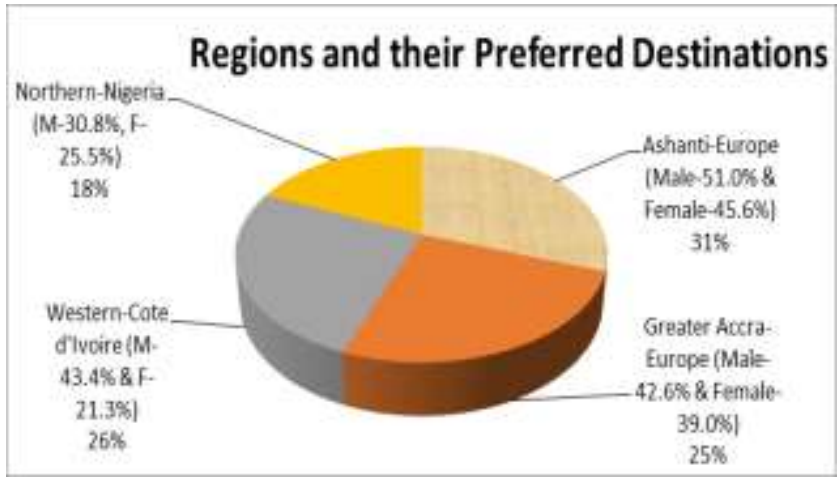

Fig. 1: Regions and their preferred destination [Source: Asiedu (2017), The Motives that drive the performance of T.E., Adapted from Ghana Statistical Service, (2010) Population Census].

Fig. 2: Employment Status of Ghanaians Abroad from 15years and above

\begin{tabular}{|c|c|c|c|c|c|}
\hline Age & Total & Employed & Unemployed & Students & Other \\
\hline 15-19 & 100.0 & 42.8 & 9.0 & 43.3 & 4.8 \\
\hline $20-24$ & 100.0 & 58.7 & 9.0 & 27.8 & 4.5 \\
\hline $25-29$ & 100.0 & 70.0 & 7.8 & 18.8 & 3.4 \\
\hline 30-34 & 100.0 & 78.1 & 6.0 & 12.8 & 3.2 \\
\hline $35-39$ & 100.0 & 81.4 & 5.4 & 10.1 & 3.1 \\
\hline $40-44$ & 100.0 & 84.2 & 4.6 & 8.2 & 3.0 \\
\hline $45-49$ & 100.0 & 85.3 & 4.0 & 7.8 & 2.9 \\
\hline $50-54$ & 100.0 & 85.4 & 4.1 & 7.0 & 3.5 \\
\hline $55-59$ & 100.0 & 84.8 & 4.8 & 7.2 & 3.2 \\
\hline $60-64$ & 100.0 & 81.8 & 6.2 & 6.4 & 5.7 \\
\hline 65-69 & 100.0 & 76.1 & 8.6 & 6.1 & 9.1 \\
\hline $70-74$ & 100.0 & 68.1 & 12.9 & 7.0 & 12.1 \\
\hline $75+$ & 100.0 & 70.8 & 10.2 & 8.6 & 10.4 \\
\hline Total & 100.0 & 76.2 & 6.1 & 14.0 & 3.6 \\
\hline
\end{tabular}


However, there are several factors of Ghanaian migration, conditions in the country serve as the major inspirations in sacrificing time spent in one's comfort zone to strive for greener pastures abroad. Also wage differences seldom become the deciding factor to migrate. Among the numerous factors aforementioned, migration is also driven by individual's desire to rise higher and change. Surely, there are corresponding costs and gains when it comes to migration. However, since many people see migration as both risk and as a form of investment, migrants continue to find their ways to grow unlimited income outside employment through engaging in transnational entrepreneurial activities. So the question is what is transnational entrepreneurship?

\section{Transnational Entrepreneurship (T.E.)}

The term "transnational entrepreneurship (T.E.)" was first used in the immigration literature as a web of contacts between Diasporas and their home countries. It was established as a form of engaging in a practice of to-and-fro movements across different borders in search of political voice and economic advantage (Saxenian 2002, Portes, et al, 2002). According to Bridge et al (2003; 23), these entrepreneurs are people with the confidence and foresight to operate in conditions where costs may be known but rewards are uncertain. Through leveraging resources from both locations, enterprising immigrants serve as agents of international business in the facilitation and promotion of bilateral investment and trade (Yeung 2002; Chen, 2007).

Scholars such as Portes et al.(2002), Min (1990) and Light et al.(2002) see transnational entrepreneurs as individuals with the ability to search the environment both in their country of origin and country of destination to mobilise resources, identify opportunities and execute actions to maximise such opportunities. They do this by maintaining a strong relationship between their destination country and country of origin. Drori et al. (2009) argued that these entrepreneurs simultaneously engage in different environments they are socially embedded, to maintain global relations that improve their ability to dynamically, logistically and creatively maximise their resource base. They take risk to innovate, provide services, employ people and through their experiences and combination of materials; create new products for the market.

Cronje et al. (1996) argued that these entrepreneurs play an important role in economic development of every country by reducing unemployment rate through their small-scale business creations. According to Florres (2010), transnational entrepreneurs have investment components located in different countries and their mode of operations is spelled by the optimization of two contexts in which they are placed. This implies that transnational entrepreneurship requires flexible, hardworking and open-minded people who can seek for information and capitalise on every opportunity to spread their entrepreneurial activities.

Contrary to the above assessment, Wong and $\mathrm{Ng}$ (2002, p.514) opined that transnational entrepreneurship is a "business in the ethnic economy which entails separate components of the enterprise being located in different countries and the transmigration of the owners in order to operate it". This really explains transnational entrepreneurship as a culturally derived, reliant and oriented on peculiar community and link of immigrant embeddedness (Sequeira et al., 2009). Migrant entrepreneurs are always engaged in one or two socially embedded environment trying to maintain global relations, maximising resource base and enhancing creativity. This activity is what Mazzucato defined as a "double engagement".

Leung (2004), and Fuller (2010) argued that immigrants involved in transnational embeddedness, engaged in cross border practices and relations, always create spaces that are used as a "point of anchorage" for their social networks to engage in information, capital and movement. This point of anchorage allows convenient and frequent access to resources and networks which enable in initiation of business ventures and opportunity recognition.

While most research on transnational entrepreneurship among Ghanaians abroad focus on economic impacts and remittances, this study focuses on the factors that drives their performances. However, before we dwell on the various factors that drives their engagement in this kind of business, we will tackle the next research questions which states that "is there a link between migration and entrepreneurial ventures?"

\section{Migration and Entrepreneurial Ventures}

Migration in this context is defined as the movement of people from one country to another country with the aim of searching for greener pasture. It normally takes place between countries with similar economic, historic, colonial and cultural ties. Ghanaians migrate to Europe and the USA due to the similar connection that exist between them; in terms of economic, social, history and culture. Littunen, (2000) argued that here are numerous factors that determine entrepreneurial activities but life situations, changes and experiences are very crucial and that is where migration comes to play part.

A study investigated the effect of labour market institution on immigration from 221 countries of origin to 15 OECD countries during the 1980 to 2006 disclosed that the difference in wages between immigrants' home of origin and foreign country is one of the deciding factors for migration (Cicagna and Sulis, 2006). What this means is that migration in most at times is driven by either the desire for individual to change his/her social status; life situation 
or gain experiences and skills, though some see it as a risk, it is also an investment.

In Ghana, employment and economic opportunities since 1957 has been a major challenge to many individuals most especially the youth. This has made travelling abroad the most lucrative business for most Ghanaian youth. Anarrfi et al., (2000) argued that there are pull and push factors that compel individuals to migrate and those factors can be financial, family, personal opportunistic and economical. This shows that conditions in the country of origin coerce or as, someone might say, motivate individuals to seek for greener pastures. Research has revealed that most Ghanaians migrate with the aim of coming back home to establish jobs so that there will be no need to search for jobs abroad (Sam, et al., 2013). This ambition of many Ghanaians shows there is a positive correlation between migration and entrepreneurial ventures

\section{Social Relations in Small-Scale Enterprises and Entrepreneurial Success}

In transnational entrepreneurship, social relations (networks) are crucial in terms of establishing the business, circulating goods and services, providing accommodation and psychological support as well as continuous improvement of socio-economic information of the two countries. Cassini (2005) stressed that money alone is not enough to develop a small-firm but issues such as trust and social responsibility are important in developing a smallscale enterprise. She however, noted that members of the migrants' social network can undermine the success of the entrepreneurial activities. Buane (1996) continued that family and social relations disadvantage entrepreneurs, by increasing unrealistic demands on their resources.

Contrary to the above assessment, Steel and Becky (1989) believed that such relations provide the individual entrepreneur the intellectual, economic, emotional and spiritual support to do their business. Mitchell (1969) opined that the contents of the links in an individual entrepreneur's social relations may compose of kingship obligation, economic assistance, religious cooperation or it may be simply friendship. Transnational entrepreneurs use these social ties to acquire or pass on information, achieve some objects as well as to influence some other people in a desired direction. The significant of social relations in maintaining and promoting small-business activities in Ghana has been noted by scholars such as Mazzucato et al., (2006) and La Ferrara (2006); Hatton and Williamson (2003), and Morris and Diana (2007). Lewis (1994) cited how firms in Nigeria have used social ties to respond to structural adjustment by retreating to 'rental havens' protected by key allies in the state.

Kloosterman (2003), McCormick and Wahba, (2003), Mesnard (2004) as well as Black and Cotalno (2008); Xiaohua and Chrysostome, (2010), Kivisto, (2001) and
Zhhou and Kim, (2006); based their argument on socioeconomic embeddness as a key element when it comes to the interaction between the demand and supply sides of business initiation and its successes. To him embeddedness is an umbrella of social networks, socio-economic and politico- institutional settings. Portes (1995) argued that embeddednesss of socio-economic relations can be grouped into structural embeddedness and relational embeddedness.

The structural embeddedness typology consists of relationship in a broader network and social relations of several individuals (Faist and Siereking, 2011). Scholars such as Granovetter (1990) and Portes; Min and Bozorgmehr (2003); Wong and $\mathrm{Ng}$ (2000) and Sensenbrenner (1993), observed that, in order to sustain and maintain these two kinds of relationships, solidarity must be built between the two partners. This will go a long way to help the transnational entrepreneurs to utilise certain sanctions to enforce trust among them to keep the relationship moving all the time. "Solidarity" in this context refers to the foundation of a collective identity which is based on rules, symbolic bonds, and shared ideas (Faist, 2008).

The second category-relational embeddedness- involves an entrepreneur's social relationship with two or more entrepreneurs (Faist and Siereking, 2011). To them, this relational embeddedness is identified by mutual reciprocity and normative expectation in interaction. Entrepreneurs through relational embeddedness can help one another and share their experiences and skills. Faist (2000) stressed that 'what one receives from the other-in this kind of social relationship-requires something in return-to make it reciprocal'. The experiences and skills shared among them marks the beginning of their reciprocal interaction (Portes and Sensenbrenner, 1993). "Personal trust" plays an important role in this kind of social relations. There is nothing that motivates and excites people like a "trust" to accomplish something special. Personal trust strengthens entrepreneurs' social relations between individuals who are part of their businesses. Faist and Siereking (2011) supported that trust is more important for small-scale business due to the risk of losing significant resources through sometimes misconduct.

\section{Trust and Transnational Entrepreneurship}

Trust in an entrepreneur's social relations brings about cooperation between the business partners. The "business partner" in this context could be the representative (manager) in-charge of the parent company and subsidiaries back home in your absent. When there is trust, there will be cooperation. Through trust, the cooperation partners would be able to understand their counterpart actions. However, both partners are supposed to follow their independent business objectives to make each one autonomous. Faist and Siereking (2011) argued that cooperation is shaped by the 
need of the partners to create mutual obligation as well as to ensure that both partners are dependent on each other. Semlinger (2003) referred to this cooperation as "bounded autonomy". Faist and Siereking, (2011) concluded that if these cooperation partners are able to dispose of the amount of autonomy and the opportunity to control one another, then there would be a symmetric dependency between the cooperating entrepreneurs.

Notwithstanding that, transnational entrepreneurs also have social relations with others who are not part of their business. Many at times, economic actions are determined by social expectations and ties. If that is the case, then how can transnational entrepreneurs protect themselves from private issues which are not supposed to be closed to their rational business activities? Evers (1991) opined that embeddedness in a person's social relations/ties needs enterprises to find a balance between social obligation on one side as well as economic survival and efficiency on the other. Besides, maintaining a balance between the creation of culture or geographic distance is crucial when it comes to embeddedness in social relations. This is because it prevents "decoupling" as Granovetter (1995) put it and thereby creating sufficient social cohesion and restricting claims to implement common values and norms to ensure a “coupling process" (Granovetter, 1995).

In business, either local or international, knowing one another at the upper levels of management is important. It is argued that knowing the person, being able to trust this person and sharing the same values are important aspect of business which is given by the image of common family origin. This becomes more important when the firm want to expand into a foreign country. Trust between the manager of the parent company and the subsidiaries are very important and can influence the actions of the various parties. Trust in a person's social relations is crucial when it comes to embeddedness in transnational entrepreneurship. In a small-scale business where most often do not have the needed managerial capabilities to engage in corporation, trust can be used to avoid loses that might come as a result of someone's misconduct.

\section{The Conceptual Framework}

The ideas of this research was organised based on Financial Independence; Economic Mobility, Success Perspective and Social Factors to achieve the study purpose which is to find out the motives that drive the performance of transnational entrepreneurship among Ghanaians Abroad. Though individuals motives for seeking self-employment are diverse and numerous and might differ on certain points, there are some basic motives common all and they are Economic Mobility, Financial Independence, Success Perspective and Social Factor. This conceptual framework was chosen because the study adopted both deductive and explanatory approach which focuses on "why or what caused" a phenomenon to occur. Fig. 2 depicts the conceptual framework.

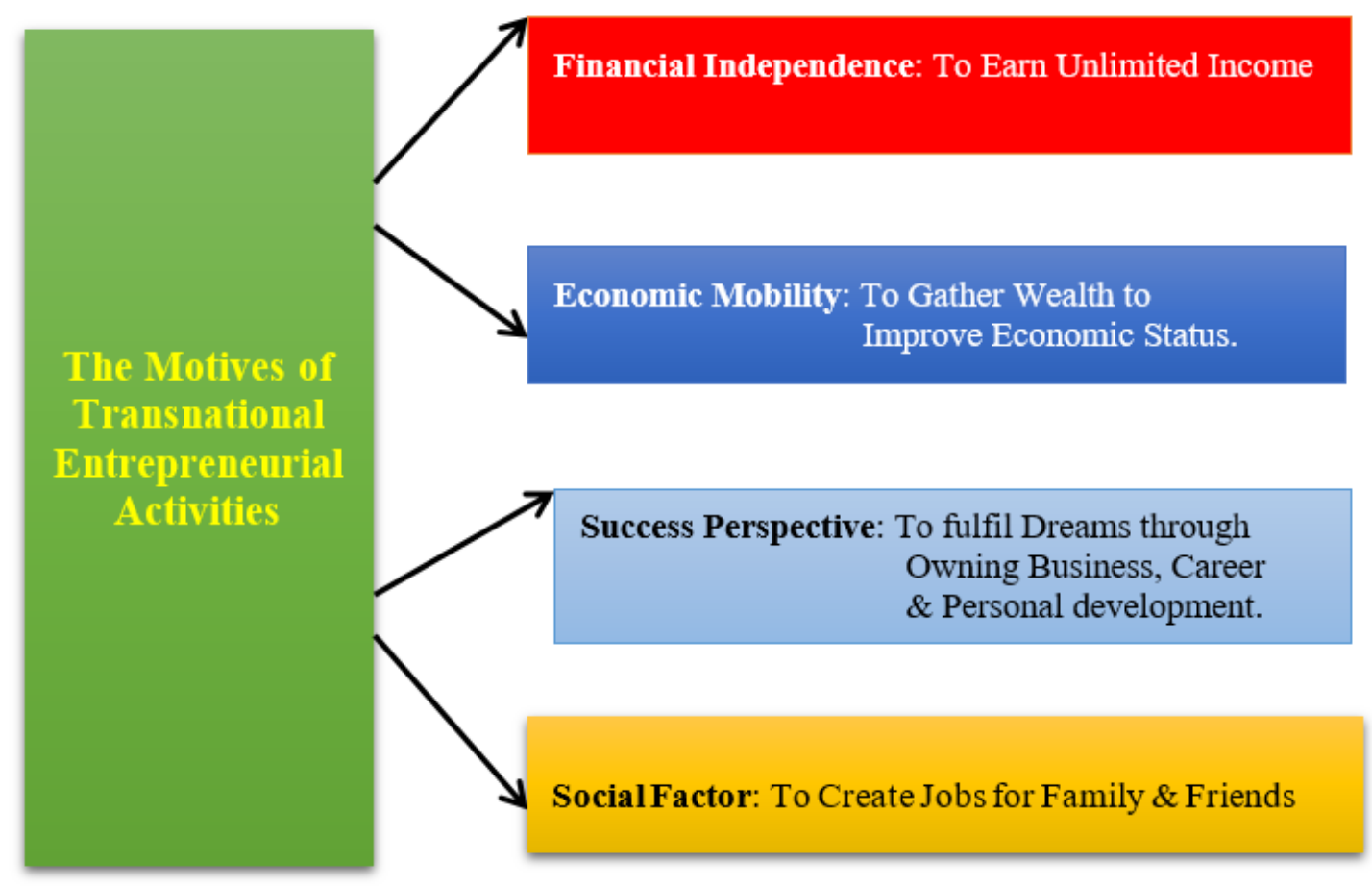

Fig. 2: The Motives that Drive the Performance of T.E.

(Source: Asiedu, E., (2017): The Motives that drive the performance of T.E.) 
What is Economic Mobility? Economic Mobility in this study is viewed as the desire, the passion and the ability to change and rise higher in the economic ladder in terms of wealth and income. Financial Independence is viewed as the state of having the desire to earn unlimited income in order to have sufficient personal wealth to live, without necessarily having to work actively for basic needs and necessities in future.

Success Perspective in this context is defined as the desire, the passion and ability to complete and fulfil the original intent or purpose for your existence or why you were created. From the definition, we could see that success is not only making a lot of money, owning a big car or a big house; but it is also about dream fulfilment, career and personal development and exploitation of endless business opportunities.

Lastly, Social Factor is the desire to perform a community or social responsibilities as a citizen in terms of creating jobs for the family, friends and the general public.

\section{Research Approach}

Though there are different empirical and theoretical insights into transnational entrepreneurship, the researcher decided to approach this topic in a way that would allow him to discover the factors that drive the performance of transnational entrepreneurship among Ghanaians abroad.

The paper adopted both deductive and exploratory approach. As a Ghanaian transnational businessman, consultant, lecturer and researcher in this field, this approach was guided by my personal experience. The approach was appropriate for gaining an insight and understanding of the kind of motives, reasons, and drivers for transnational entrepreneurship. Smith (2007) argued that an exploratory approach to transnational entrepreneurship is appropriate, most especially for research that focuses on African country like Ghana.

The researcher also used a survey strategy to collect data from Ghanaian transnational entrepreneurs who were engaging continuously in cross-border economic transaction between United Kingdom, USA and Ghana. The aim was to figure out the various motives, reasons, and drivers that pushed these people into this kind of business and the kind of mobility involved.

\section{Methodology}

Using data collected from Ghanaians living in the United Kingdom, and the USA; this research examined the motives that drive the performance of transnational entrepreneurship, the mobility involved and why such businesses normally fail.

In 2013-2017, a field research was carried-out by interviewing Ghanaians living in Europe; more precisely, United Kingdom and the USA on their motives for the involvement in transnational entrepreneurial activities. At the start of the studies, exploratory and open characters of semi-structured interviews were used. Those interviewed were the entrepreneurs who were active in a myriad of economic sectors (see table 2). Some of these entrepreneurs were met in church, at workplace and many social gatherings in Europe and the USA. Most of the interviewees were mobile in different ways and had created different ways of administering their businesses. In view of this, the study primarily obtained an overview of their fields, its diversity and complexity. The Population size of the study included.

Table 2: Population of Respondents

\begin{tabular}{|lll|}
\hline Sector & $\begin{array}{l}\text { Sample } \\
\text { Size }\end{array}$ & $\begin{array}{l}\text { Percentage } \\
(\%)\end{array}$ \\
\hline Restaurant Operators & 30 & 25 \\
\hline Car Dealers & 5 & 4 \\
\hline $\begin{array}{l}\text { Others like Beer Bar } \\
\text { Operators }\end{array}$ & 15 & 13 \\
\hline $\begin{array}{l}\text { Second Hand Clothing } \\
\text { Dealers }\end{array}$ & 60 & 50 \\
\hline Micro-Finance Operators & 5 & 4 \\
\hline Educational Operators & 5 & 4 \\
\hline TOTAL & $\mathbf{1 2 0}$ & $\mathbf{1 0 0}$ \\
\hline
\end{tabular}

Data collection was done based on questionnaires and interviews. These two instruments were selected because they are cheap, quick and provide moderately high measurement validity. The questionnaires were designed based on the extensive fieldwork and existing literature and were grouped into demographic; personal and work experiences in abroad dimension; general perception about Ghana's business environment; family lives and transnational experience. There was pre-test on a few individuals and the pre-test revealed that many Ghanaians abroad were not comfortable with the filling of surveys like placing numbers in likert scales. In view of that, the researcher adopted many closed-ended questions with fixed response groups.

The interviews on the other-hand were done in London and Oxford in the United Kingdom respectively. The one which was done in London was done in three public forums in a Ghanaian community in London, while the one in Oxford was done on Sundays after church services in 2013-2014. The interview continued in 2015-2016 through Social Network Sites such as Facebook, Twitter, Google+ and Whatsapp with friends who were into transnational entrepreneurships. The interviews were done with four people (see Findings and Discussions) due to their proximity to the researcher. Out of the four people interviewed, three (3) of them were living in the UK and One (1) lives in the USA. 
In an attempt to ensure respondents understanding of the topic, the researcher explained transnational entrepreneurship in both English and Akan language in the questionnaire as "those who reside in Europe and America; and frequently move between their home country and the various countries of destination for the success of their businesses". In Akan “W)n a )te akwantuo w) EnglesiBronikurom ne America, na )di ak)neaba w) Ghana ne aburokyirman so; esan se won ndwuma bek) so nti".

\section{Characteristics of the Respondents}

The Table 3 shows the demographic variables and descriptions of the 76 respondents who took part in the study. The aim of this table was to answer the research questions on demographical variables of the respondents based on gender; age, education, ethnic background, business location in Ghana, employment status, the kind of business they are involved and the person who manages their businesses in Ghana.

\section{Findings and Discussions}

Table 3: Demographic variables and descriptions

\begin{tabular}{|c|c|c|}
\hline Variables & Descriptions & Frequency/Percentage \\
\hline $\begin{array}{l}\text { Are You Transnational Entrepreneur? } \\
(\mathrm{N}=120)\end{array}$ & $\begin{array}{l}\text { (1). Yes } \\
\text { (2.) No / } \\
\text { (3). No Answer }\end{array}$ & $\begin{array}{l}76(63.3 \%) \\
42(35 \%) \\
2(1.67 \%)\end{array}$ \\
\hline $\begin{array}{l}\text { IF YOU ANSWERED YES, THEN } \\
\text { CONTINUE PLEASE. }(\mathbf{N}=76)\end{array}$ & & \\
\hline Gender & $\begin{array}{l}\text { (1). Male } \\
\text { (2). Female }\end{array}$ & $\begin{array}{l}50(65.79 \%) \\
26(34.21 \%)\end{array}$ \\
\hline & (1). 18-30 & $11(14.47 \%)$ \\
\hline How old are you? (Age) & $\begin{array}{l}\text { (2.) } 30-45 \\
\text { (3.) } 45-60 \\
\text { (4). } 60-65+\end{array}$ & $\begin{array}{l}18(23.68 \%) \\
35(46.05 \%) \\
12(15.79 \%)\end{array}$ \\
\hline Education & $\begin{array}{l}\text { (1). Phd, } \\
\text { (2). MBA/MSc/MA, } \\
\text { (3). BA/Bed. } \\
\text { (4) Diploma } \\
\text { (5)High School/below }\end{array}$ & $\begin{array}{l}9(11.84 \%) \\
23(30.26 \%) \\
30(39.47 \%) \\
8(10.53 \%) \\
6(7.89 \%)\end{array}$ \\
\hline Ethnic Background & $\begin{array}{l}\text { (1). Ashanti, } \\
\text { (2) Greater Accra, } \\
\text { (3). Brong Ahafo, } \\
\text { (4) Others }\end{array}$ & $\begin{array}{l}40(52.63 \%) \\
21(27.63 \%) \\
6(7.89 \%) \\
9(11.84 \%)\end{array}$ \\
\hline Parent Business Location in Ghana & $\begin{array}{l}\text { (1). Kumasi, } \\
\text { (2). Accra, } \\
\text { (3) Sunyani, } \\
\text { (4) Others }\end{array}$ & $\begin{array}{l}30(39.47 \%) \\
33(43.42 \%) \\
3(3.95 \%) \\
10(13.16 \%)\end{array}$ \\
\hline Employment Status & $\begin{array}{l}\text { (1). Full Time } \\
\text { (2). Part-Time } \\
\text { (3). Self-Employed } \\
\text { (4). Not Working }\end{array}$ & $\begin{array}{l}15(19.74 . \%) \\
17(22.37 \%) \\
25(32.89 \%) \\
19(25 \%)\end{array}$ \\
\hline What kind of business are you into? & $\begin{array}{l}\text { (1). Service Business } \\
\text { (2). Merchandising Business } \\
\text { (3). Manufacturing Business }\end{array}$ & $\begin{array}{l}26(34.21 \%) \\
45(59.21 \%) \\
8(10.53 \%)\end{array}$ \\
\hline Who Manages Your Business in Ghana? & $\begin{array}{l}\text { (1). Family } \\
\text { (2). Old School Friend } \\
\text { (3). Church Member/Pastor } \\
\text { (4). Other }\end{array}$ & $\begin{array}{l}45(59.21 \%) \\
13(17.11 \%) \\
14(18.42 \%) \\
4(5.26 \%)\end{array}$ \\
\hline
\end{tabular}

Source: Asiedu E, 2017. Transnational Entrepreneurship and Ghanaians Abroad: What are the Motives? 
A total of 76 questionnaires were returned out of 120 distributed questionnaires; giving a response rate of $63.3 \%$. The majority of the respondents were males representing $65.79 \%$ and the least were female representing $34.21 \%$. The results demonstrate that most of the respondents came from the age groups of 45-60 years representing $46.05 \%$. The least were the young respondents with then age groups of $18-30$ representing $14.47 \%$ of the respondents. Other respondents came from age groups of 30-45 representing $(23.68 \%)$ and over 60 years were $15.79 \%$. The findings also indicated that majority of the respondents in this study held bachelor's degrees (39.47\%), followed by Master's degrees $(30.26 \%)$, followed by Phd $(11.84 \%)$ and those held professional diploma qualifications in the field of specialization represented $10.53 \%$. The other respondents that took part in the study were high school certificates holders $(7.89 \%)$.

The results show that most of the respondents came from Ashanti region with a frequency rate of $40(52.63 \%)$; followed by the Greater Accra region (27.65\%), BrongAhafo region came third with $7.89 \%$ and $11.84 \%$ represented the other seven regions in Ghana. This explains that Ashanti Region population in Ghana are more into transnational entrepreneurial activities than any other region in Ghana-West Africa.

"One of the interviewees, Mr. Lawrence Opoku-a family business-providing a service for transnational exchange told me "I am the owner of a cargo business, called Agyakoo shipping logistic. I offer the service of shipping goods from here in UK to Ghana. I have a brother back home who manages the business. I have three branches in Ghana; Kumasi, Accra and Sunyani but my main office is in Kumasi. Why did you enter into transnational entrepreneurship? He laughed and said-You know I am an Ashanti guy and doing business is my hobby" (Interview with Mr.Opoku, August, 2013)'”.

The results also demonstrate that majority of the respondents were self-employed $(32.89 \%)$; followed by $22.37 \%$ of part time workers, $19.74 \%$ Full-Time workers and $25 \%$ represented the respondents who were not working and only concentrating on their businesses.

When it comes to the kind of businesses they were involved; the results show that, the majority of the respondents 45 $(59.21 \%)$ were into merchandising businesses. Merchandising business in this context refers to the kind of business in which entrepreneurs buy products at wholesale price and sells the same at retail price. These entrepreneurs make profit by selling the products at prices higher than the purchase costs. This system is called "buy and sell" businesses. In Ghana it is called "t)-na-t)n" in Akan language. They purchase goods such as second-hand clothes, tvs, computers, cars, spare parts, phones and accessories, and send them to Ghana where their representatives help to sell them. "According to Nana Kwaku, a spare parts dealer in Oxford told me that "I make lots of profit by selling these products at prices higher than their purchase costs (Interview with Nana Kwaku, August, 2013". A merchandising business sells a product without changing its form. Notable examples are convenience stores, grocery stores, distributors and other sellers.

The second majority of the respondents were into service business with a frequency rate of $26(34.21 \%)$. A service business is another type of business which provides intangible products (that's products with no physical form). This type of business offers professional expertise, skills and other similar products. Notable examples of such businesses include hair salons, banks, micro finance, accounting firms, law firms, repair shops, schools, and many more. The least of the respondents (10.53\%) were involved in manufacturing businesses. In manufacturing businesses, the business owner purchases products in a form of raw materials with the intention of using them to make or produce a new product. A manufacturing business combines raw materials, labour, and factory overheads in its production process. The manufactured goods will then be sold to customers.

In a quest to answer "who manages their businesses?" the majority of the respondents (59.21\%) agreed that family members run their businesses in their absence. In a transnational business structure, the entrepreneurs achieve integration by appointing specific type of managers. The country or regional managers act as a focal point for customers and oversee all products and functions performed their area. Conversely, the managers oversee the activities of a particular function such as marketing, technology, or manufacturing. The remainder of the respondents were drawn from church members/pastors (18.42\%); old-school friends $(17.11 \%)$; and others $(5.26 \%)$, all in the name of trust.

One of the interviewees, Juliana Amoakowaa explained that upon establishment of the business, she was required to identify a reliable person who could be trusted and administer the daily affairs of the business in her absence. This activity is what Mazzucato defined as a "double engagement". It is double engagement because she is engaged in economic activities of two countries. See the conversation that went on between the researcher and Miss Juliana Amoakowaa; "For me (Juliana Amoakowaa Speaks) "I purchase
goods in this country and send them to Ghana where
my representatives (my mum and siblings) help to
sell them. Though engaging in this kind of business
can be frustrating and difficult, yet I am motivated to
do it. Amoakowaa lives in London (Waterloo). 
According to her "I am the head of Amoakowaa second-hand clothing's in Ashtown-Kumasi. How did you get this entrepreneurial idea? I got the idea of establishing this business in Ghana from my mum, Maame Amoakowaa. Oh so your mum helped you! She replied, Yes! My mum helped me to set the business in Kumasi. What do you do? I buy secondhand clothes here in UK and send them to Ghana. I distribute the "fos bail" as in Akan to over 20 people within Kumasi metropolis. What do you do to keep the business moving since you are here in London? I am constantly on telephone conversation with my mum and siblings to keep myself informed about the business. Though I am in London, I still take responsibilities for certain things that cannot be handled by my old mum. I also fly to Ghana every year to see the welfare of the business".

Wow! This proves that social relations are very important in this type of business. But wait! Look at how difficult this kind of business could be: always on phone and to the extent of travelling to Ghana every year, all because of her business. Hmmmm! If that is the case, then what really drives them to engage in this kind of entrepreneurial activities? This set the grounds for the main objective of this study "What are the motives that drive the performance of transnational entrepreneurship?"

\section{Motives that Drives the Performance of Transnational Entrepreneurship}

This research is aimed at assessing the motives behind the performance of transnational entrepreneurship among Ghanaians abroad on the basis of financial independence, economic mobility, social factors, and success perspective. The respondents were asked to measure the motives for the performance of transnational entrepreneurship based on a scale of 1-4, with average scores less than 2 means "it doesn't form part of the motives that drive the performance of transnational entrepreneurship". The results were tabulated in the Table 4.

The results show that the overall mean score for the respondents on economic mobility was 2.4. Economic mobility in this study refers to the individual's ability to gather wealth to improve their economic status through business creation or any other legal means and it is usually measured in income. Though the overall rating was 2.4, there was a consensus among the respondents on economic mobility because the range of perspective among the participants was small from 2.2 to 2.8. Statistically, however, there was a significant difference when ANOVA Analysis was conducted and that's $\mathrm{F}(4,30)=0.74, \mathrm{P}<.0 .5$. Interestingly, the respondents from Auto-Mobile Industries (2.8) rated the performance of economic mobility higher than Restaurant Operators (2.2) and that shows extreme side of range. To amass everything, we can easily see from the table that economic mobility is one of the motives that drive the performance of transnational entrepreneurship among Ghanaians abroad since the figures were all above 2.0 with exception of "Others" that did not rate it at all.

On the Financial Independence perspective, the overall means score was 2.9 which shows that the respondents viewed financial independence as one of the main reasons that drives the performance of transnational entrepreneurship among Ghanaians abroad. From the figures in the table, it is obvious that though, the overall rating was 2.9; there is a huge gap of perspective among the respondents from 2.4 to 3.3. Interestingly, the Auto-Mobile Dealers rated the performance of financial independence higher (3.3) than the Micro-Finance Operators and these differences are not statistically significant, $F(5,69)=4.99$, $\mathrm{P}>$.0.5. In general, the overall rating on financial independence was very convincing signifying that most Ghanaians entered into transnational entrepreneurship with the potential aim of earning unlimited income.

Table 4: Results from Respondents Survey

\begin{tabular}{|c|c|c|c|c|c|c|c|}
\hline Perspectives & $\begin{array}{l}\text { Restaurant } \\
\text { Operators }\end{array}$ & $\begin{array}{l}\text { Auto- } \\
\text { Mobile } \\
\text { Dealers }\end{array}$ & $\begin{array}{l}\text { Second- } \\
\text { Hand } \\
\text { clothes } \\
\text { Dealers }\end{array}$ & $\begin{array}{l}\text { Educational } \\
\text { Operators }\end{array}$ & $\begin{array}{l}\text { Micro- } \\
\text { Finance } \\
\text { Operators }\end{array}$ & $\begin{array}{l}\text { Others e.g. } \\
\text { Beer Stations } \\
\text { Operators }\end{array}$ & $\begin{array}{l}\text { Mean } \\
\text { Score }\end{array}$ \\
\hline $\begin{array}{l}\text { Economic } \\
\text { Mobility }\end{array}$ & 2.2 & 2.8 & 2.3 & 2.4 & 2.4 & $\mathrm{n} / \mathrm{a}$ & 2.4 \\
\hline $\begin{array}{l}\text { Financial } \\
\text { Independence }\end{array}$ & 2.6 & 3.3 & 2.6 & 2.5 & 2.4 & 3.1 & 2.9 \\
\hline $\begin{array}{l}\text { Success } \\
\text { Factors }\end{array}$ & 3.2 & 2.4 & 2.8 & 2.4 & 2.7 & 2.8 & 2.8 \\
\hline Social Factors & 2.9 & 2.6 & 1.6 & 2.1 & 2.1 & $\mathrm{n} / \mathrm{a}$ & 2.2 \\
\hline Mean Score & 2.5 & 3.0 & 2.3 & 2.4 & 2.4 & 3.0 & 2.6 \\
\hline
\end{tabular}

(Source: Asiedu E, 2017. Transnational Entrepreneurship and Ghanaians Abroad: What are the Motives?) 
The overall mean score for the respondents on the Success Factors was 2.8. This means that the respondents viewed Success Factors as one of the significant motives that drives the performance of the transnational entrepreneurial ventures. This means many migrants venture into transnational entrepreneurship because they want society to see their success in life through owning a business (that's "be their own bosses"), manage their own time as part of fulfilling their dreams. The respondents declared that entering into transnational entrepreneurship was an avenue to fulfil their dreams. Though the overall rating was 2.8, there was a wide range of perspective among the respondents from 2.4 to 3.2 . Based on the table stats, Restaurant Operators (3.2) rated the Success factors higher Auto-Mobile Dealers (2.4) and Educational Operators (2.4). More so, these differences are statistically significant since $\mathrm{F}(5,70)=1.86, \mathrm{p}<.0 .5$. The rating 2.8 on success factors was not a surprise figure from the respondents because the respondents have made it clear that they want to have unlimited income by rating financial independence 2.9.

Many of the interviewees who also filled the questionnaires explained that they were tired of the corporate set-up and the early morning wake-up all in the name of beating time to work. They also argued that they ventured into transnational entrepreneurship in order to manage their own time and this has made them more flexible to work on their businesses and other ventures. According to them, they had busy schedules when they were working for someone but now they have been able to turn their hobbies into business opportunities. Success has been the main motive that drives the performance to explore endless business opportunities.

The results also show that the overall mean score for the 73 respondents under the social factors was 2.2 out of 4.0 grading point. This means that the 73 respondents viewed the social factors as one of the motives that drive the performance of transnational entrepreneurship among Ghanaians abroad. Though the overall rating was 2.2, there was a wide range of perspective among the respondents from 1.6 to 2.9. Respondents operating restaurants interestingly rated social factors higher (2.9) than SecondHand Clothes Dealers (1.6). Based on ANOVA analysis results, these differences are statistically significant, F (4, $30)=1.88, p<.0 .5$. One of the restaurant operators who rated social factors higher than any others explained that one of the motives of going into business was to create jobs for the $5.5 \%$ unemployment rate in Ghana. To them entering into transnational entrepreneurship has helped them to create more jobs for their families and friends back home. Entering into transnational entrepreneurship is an avenue to help society and people and the entire Ghanaian economy to thrive.

\section{Summary and Conclusion}

The study assessed the motives that drive the performance of transnational entrepreneurship among Ghanaians abroad. The study began with a brief history of Ghana its economy and employment status. The study further reviewed and discussed the meaning of transnational entrepreneurship, and the link between migration and entrepreneurial ventures. It discussed the kind of influence social relations such as family, friends and ethnic background have on such entrepreneurial activities. The study also talked about the kind of business and the industry these entrepreneurs are engaged in and the mobility involved. The motives that drive the performance of transnational entrepreneurial activities among Ghanaians were also discussed on the basis of Economic Mobility; Financial Independence; Success Perspective and Social Factors.

The study has proven that most of the transnational entrepreneurs from Ghana are into small-medium business establishment as referred in the literature review earlier. It was discovered that operating in two different countries can increase their ability to discover opportunities, develop experience and make connections. The study also revealed that migration exposes individuals to some important information which can help them to build upon their skills and knowledge. These are the reasons why most entrepreneurs extend their businesses beyond ethnic boundaries and operate within the corridors of two countries simultaneously (Flores 2010, and Drori, 2009).

The study revealed that the successes of transnational entrepreneurial activities depend on individual characteristics, institutional regulations, firm organisation, and the external environment. The findings showed that, in Ghana, most successful transnational entrepreneurs are male, educated and middle aged. Kiggundu (2000) explained that education, work experience, training, overseas visits, apprenticeship and other human development initiatives are influential factors for entrepreneurial failure or success. The study disclosed that social relations provide the individual entrepreneur the intellectual, economic, emotional and spiritual support to do their business. We learnt that the majority of the respondents agreed that their family members run their businesses in their absence.

\section{Recommendation}

Based on the above findings, it is recommended that transnational entrepreneurs should carefully study their attitudes, the degree of embededdness in the home country, personal and the institutional regulations of the destination countries to ensure a successful business. It is also recommended that social relations with family and friends are very crucial in this type of business; therefore transnational entrepreneurs should always draw closer to these people when trying to enter into this kind of business. 
Future transnational entrepreneurs should also be aware that; education, work experience, training, overseas visits, apprenticeship and other human development initiatives are influential factors for entrepreneurial failure or success

\section{Limitation and Future Research}

While interpreting the findings of the research, it is necessary to know the limitations of this study. The first deals with the sample for the study which was drawn from immigrant entrepreneurs from Ghana. Also the research was designed cross-sectional; therefore, it is subject to hindrances of cross-sectional studies. The study is subjected to the bias of the respondents, therefore, $100 \%$ accuracy cannot be guaranteed. In future, other researchers can also research on the following questions: what is the role diaspora and immigration in transnational entrepreneurship? Does transnational entrepreneurship concentrate on particular markets or location? What kinds of international resource flows are associated with transnational entrepreneurship?

\section{References}

Anarfi JK and Kpakpa M (2013) Migration and Urbanization (Chapter 10) in the 2010 Population and Housing Census, Ghana Statistical Service, National Analytical Report.

Anarfi JK, Nabila JS, Awusaba-Asare K and Nsowa-Nuamah NNN (2000) Push and Pull Factors of International Migration. Country Report: Ghana. Eurostat Working Papers 2000/E(10).

Asiedu E (2017) Transnational Entrepreneurship and Ghanaians Abroad: What are the Motives? A Case Study in Europe and United States of America. Unpublished.

Beauchemin C and Schoumaker B (2005) Migration to cities in Burkina Faso: does the level of development in sending areas matter? World Development 33: 1129-1152.

Black R (2004) Migration and Pro-poor Policy in Africa. Development Research Centre on Migration, Globalisation and Poverty Working Paper no. C6.

Black R and Castaldo A (2008) Return Migration and Entrepreneurship in Ghana and Cote D'ivoire Sussex Centre for Migration Research. University of Sussex, Falmer, Brighton BN1 9SJ, UK.

Bridge S, O’Neill K and Cromie S (2003) Understanding Enterprise, Entrepreneurship and Small Business New York: Palgrave.

Buane SK (1996) Entrepreneurship: A Contextual Perspective. Lund: Lund University Press.

Cassini S (2005) Negotiating Personal Success and Social Responsibility: Assessing the Developmental Impact of Ghanaian Migrants' Business Enterprises in Ghana. International School of Humanities and Social Sciences, (Master's Thesis, University of Amsterdam).

Chen WH (2007) Spinning Transnational Webs. Ethnic Entrepreneurship and Social Networks in the Internet Age. Unpublished Phd Dissertation, University of Toronto.
Chrrysostome E and Xiaohua L (2010) Immigrant Entrepreneurship: Scrutinising a Promising Type of Business Venture. Thunderbird International Business Review, 52(2), 77-82

Cicagna C and Sulis G (2006) On the Potential Interaction between Labour Market Institutions and Immigration Policies. International Journal of Manpower 36(4): 441-468.

Cronje GJ, du Toit de, J Mol AJ, van Reenen MJ and Motlatla MDC (1996) Introduction to Business Management, Johannesburg: International Thomson Publishing (Southern Africa)

Dana L and Morris M (2007) Towards a Synthesis. A Model of Immigrant and Ethnic Entrepreneurship. In: Dana L (Ed) Handbook of research on the ethnic minority entrepreneurship. A Co-Evolutionary View on Resource Management. Cheltenham, UK., Edward Elgar. pp. 803811.

Daniels L and Mead DC (1998) The Contribution of Small Enterprises to Household and National Income in Kenya. Economic Development and Cultural Change 47: 45-71.

Drori I, Honig B and Wright M (2009) Transnational Entrepreneurship An Emergent Field of Study. Entrepreneurship Theory and Practice 33(5): 1001-1022.

Drori I, Honig B, and Ginsberg A (2006) Transnational Entrepreneurship: Toward a Unifying Theoretical Framework. Academy of Management Proceedings, Q1Q6.

Faist T (2000) The Volume and Dynamics of International Migration and Transnational Social Spaces Oxford, UK, Clarendon Press.

Faist $\mathrm{T}$ and Siereking N (2011) Unravelling Migrants as Transnational Agents of Development: Social Spaces in Between Ghana and Germany, Munster: Lit-Verlag

Fuller DB (2010) Networks and Nations: The Interplay of Transnational Networks and Domestic Institutions in China's Chip Design Industry. Int J Technol Manag 51(24): $239-257$

Ghana Statistical Service (2013) 2010 Population and Housing Census: National Analytical Report

Granovetter M (1985) Economic Action and Social Structure: The Problem of Embeddedness. American Journal of Sociology 91(3): 481-510.

Granovetter M (1995) The Economic Sociology of Firms and Entrepreneurs, pp 128-165 in Portes, A (ED), The Economic Sociology of Immigrant Essays on Networks, Ethnicity and Entrepreneurship New York Russel Sage Foundation

Hatton TJ and Williamson JG (2003) What Fundamentals Drive World Migration Wider Discussion Paper, 2003/2

Hisrich RD (2005) Entrepreneurship $7^{\text {th }}$ Edition Boston Accessed on 2/01/2017 Online: http//wwwcsbuncwedu/people/rowej/classes/mba533old/ mba53301class6studentpdf 
IndexMundi (2016) Online: http://wwwindexmundicom/ghana/

Kayanula D and Quartey P (2000) The Policy Environment for Promoting Small and Medium-Sized Enterprises in Ghana and Malawi IDPM Finance and Development Research Programme. Working Paper Series 15

Kim S and Zhou M (2006) Community Forces, Social Capital and Educational Achievement: The Case of Supplementary Education in the Chinese and Korean Migrant Communities. Harvard Educational Review 76(1): 1-29.

Kloosterman R and Rath J (2003) Immigrant Entrepreneurs Venturing Abroad in the Age of Globalization Oxford/New York Berg/University of New York Press

Krivisto P (2001) Theorizing Transnational Immigration: A Critical Review of Current Efforts. Ethnic Racial Status 24: 549-577.

La Ferrara E (2003) Kin Groups and Reciprocity: A Model of Credit Transactions in Ghana. The American Economic Review 93: 1730-1751.

Leung MWH (2004) Chinese Migration in Germany: Making Home in Transnational Space Frankfurtiko Verlag

Lewis P (1994) Economic Statism Private Capital and the Dilemmas of Accumulation in Nigeria. World Development 22: 437-451.

Ley D (2006) Explaining Variations in Business Performance Among Immigrant Entre preneurs in Canada. J Ethn Migr Stud 32:743-764.

Light I, Zhou M and Kim R (2002) Transnationalism and American exports in an English-speaking world. International Migration Review 36(3): 702-725.

Littunen H (2000) Entrepreneurship and the Characteristics of the Entrepreneurial Personality. International Journal of Entrepreneurial Behaviour and Research 6(6): 295-309.

Mazzucato V, Kabki M and Smith L (2006) Transnational migration and the economy of funerals: Changing practices in Ghana. Development and change 37(5): 10471072 .

McComick B and Wahba J (2003) Return International Migration and Geographical Inequality: The Case of Egypt. Journal of African Economies 12: 500-532
Min PG (1990) Problems of Korean Immigrant Entrepreneurs. International Migration Review 24: 436-455

Min PG and Bozorgmehr M (2003) United States: Entrepreneurial Cutting Edge

Mitchell JC (1969) Social Networks in Urban Situations Analysis of Personal Relationships in Central Africa Towns Manchester: Manchester University Press

Portes A and Sensenbrenner J (1993) Embeddedness and Immigration Notes on the Social Determinants of Economic Action. American Journal of Sociology 98(6): 1320-1350.

Portes A, Guarnizo LE and Haller WJ (2002) Transnational Entrepreneurs: An Alternative Form of Immigrant Economic Adaptation. American Sociological Review 67(2): 278-298.

Sam GA, Boateng FO and Oppong-boakye PK (2013) Remittances from abroad: The ghanaian household perspective. International Journal of Business and Social Science 4(1).

Saxenian A (2002) Transnational Communities and the Evolution of Global Production Networks The Cases of Taiwan, China and India. Industry and Innovation 9(3): 183-202.

Sequeira JM, Carr JC and Rasheed AA (2009) Transnational entrepreneurship: determinants of firm type and owner attributions of success. Entrepreneurship Theory and Practice 33(5): 1023-1044.

Smith RC (2003) Diasporic Membership in Historical Perspective: Comparative Insights from the Mexican, Italian and Polish Cases. Int Migr Rev 37: 722-759.

Wong LL and $\mathrm{Ng} \mathrm{M} \mathrm{(2000)} \mathrm{The} \mathrm{Emergence} \mathrm{of} \mathrm{Small}$ Transnational Enterprise in Vancouver The Case of Chinese Enterpreneur Immigrants. International Journal of Urban and Regional Research 26(3): 508-530.

Yeung HW (2002) Entrepreneurship in International Business: An Institutional Perspective. Asian Pacific Journal of Management 19: 29-61. 